\title{
Hypochondria as a Poetic Disease: Medicine and Ethics in the Case of an Early Nineteenth-Century Hungarian Poet
}

\section{Gábor Vaderna}

\author{
Eötvös Loránd University / Research Centre for the Humanities \\ vaderna.gabor@abtk.hu
}

Medical knowledge reached a wider range of social strata in the eighteenth and early nineteenth centuries. Popular medical books described diseases and how to cure them, and the press regularly addressed the topic of having a healthy body. Meanwhile, representations of the perfect body became an increasingly important problem for neoclassical art. This case study investigates how Dániel Berzsenyi (1776-1836), one of the important Hungarian poets of the early nineteenth century, thought about the human body. For him, the representation of the body was, on the one hand, an artistic problem which raised questions concerning manners of imitation and, on the other hand, an artistic problem which was associated with the display of human virtues and thus with ethical discourse. Berzsenyi gave an account of his illnesses, which can be traced back to hypochondria, in a private letter. His self-analysis has three layers. First, his private letter could be read as part of a sensible epistolary novel. I argue that Berzsenyi introduced himself as a sensible hero, who was ill because of his own uncontrollable emotions. Second, hypochondria has a medical context. Considering the continued influence, in Berzsenyi's time, of the ancient doctrine of bodily fluids, I demonstrate that this disease may have become a mental illness associated with poets. The reason for this is that the emotions entertained by the sensible man led to the emergence of physical symptoms which were associated with the hardly definable concept of hypochondria. Third, one's relationship to one's body could be a moral issue. Berzsenyi attempted to assert his own moral superiority by describing his own illness. Thus, his letter also fit into a moral context of the contemporary theoretical debates in which he was involved. My paper shows how aesthetics, ethics, and medicine were interconnected and how different forms of knowledge circulated between the forums of the arts and other social forums.

Keywords: hypochondria, sensibility, poetry, medicine 
Morieris, non quia aegrotas, sed quia vivis

Seneca (Ep. 78,6)

\section{Self-Fashioning and Psychology}

"What a task it is to build a bridge between contemporary psychology and the perception of the historical world!" Wilhelm Dilthey wrote enthusiastically in 1894, though he then cautioned that this goal could only be reached step by step. We can capture the individual together with history by looking for the inner meaning that connects them. ${ }^{1}$ This approach has had a significant influence on modern literary history and theory and also on the ways in which we converse about literature in everyday life. History determines the subject, while the subject's intellectual achievement influences history. However, what is the relationship between the historical subject's psyche and the psyche of the person who is now thinking about him? I. A. Richards gave his Cambridge students poems to analyze without telling them anything about the origins or authors of the text. In his 1929 Practical Criticism, he claimed that thanks to the persistent work of his students who first encountered serious difficulties in text comprehension, he became able to conduct a close analysis of the poems. Richards thus distanced himself from the abuse of psychology, and he proposed that the literary text should only influence the reader's psyche, and we should ignore the psychology of historical subjects. ${ }^{2}$ Still, can we exclude all factors that lie outside the literary text so easily? Although twentieth-century literary theory, which primarily focused on the linguistic achievements of literary works, tried to relegate the psychological contexts to the background (or at least to tame psychology), talk of history meant that elements of psychology were sneaked back into the discussion, nonetheless.

The problem thus has a dual nature. On the one hand, historical agents thought something about themselves, and they also expressed their opinions about their own essence. This is the problem of self-fashioning, research on which was initiated by New Historicism. ${ }^{3}$ According to New Historicism, historical subjects construct their identities within the constraints of their opportunities, and they fashion the social image through which others perceive them. On the other hand, pre-modern subjects are very difficult to interpret

1 Dilthey, "Ideen über eine beschreibende und zergliedernde Psychologie," 240.

2 Richards, Practical Criticism, 321-23.

3 Greenblatt, Renaissance Self-Fashioning. 
without considering modern psychological constructs. When historical agents write about themselves, it can easily tempt us to force familiar psychological clichés onto our "victims."

In the following, I will present a case that can be understood through the concept of modernity, but which precedes Freudian psychology and its institutionalization.

It is the year 1820, and we will peek into the private correspondence between two Central European poets. One of them was sick, and he was attempting to decipher his illness. We will see how medicine, aesthetics, and ethics were intertwined in his writings.

\section{Sensible Self}

In the discussion which follows, I introduce several nineteenth-century Hungarian poets. Hungarian literary history at the beginning of the twentieth century (Geistesgeschichte in particular) paid considerable attention to our protagonist, Dániel Berzsenyi (1776-1836), who researched the relationship between psychology and history. Berzsenyi was an ideal candidate to make this connection. We know very little about his life, and what he claimed about himself is occasionally based on verifiably false facts. He came out of nowhere, no one knew who he was or where he came from, and no one knew how or from whom he had learned to write poems. The best-known poet of the era and the other character in our story, Ferenc Kazinczy (1759-1831), published Berzsenyi's poems, though they never met in person. Berzsenyi's volume of poetry was published in 1813, followed by the expanded version in 1816. The poems instantly became an important part of Hungarian poetry (and continue to be so to this day). But no sooner had Berzsenyi arrived on the literary scene in Hungary than he suddenly disappeared from the prying eyes of the public. In 1817, Berzsenyi received a negative review from a young man named Ferenc Kölcsey (1790-1838) which upset him, and so he barely spoke to anyone afterwards. Kölcsey was also a poet (he later wrote the poem that became the current national anthem of Hungary). When Berzsenyi died in 1836, Kölcsey apologized to him in his eulogy.

The lack of sources concerning the details of Berzsenyi's life became the point of departure for psychological explanations of his poetry. At the

4 For criticism on the problem see McGann, "Rethinking Romanticism." 
beginning of the twentieth century, Dániel Berzsenyi was popular as an author among the supporters of a thriving Geistesgeschichte (as well as among those who, although they distinguished themselves from the adherents of Geistesgeschichte, were still engaged in something very similar). I will mention only a few examples. Gábor Halász attributed the breakdown to the clash between the poet's true nature and his principles, ${ }^{5}$ while Ferenc Fejtô attributed it to the lack of selfconfidence. ${ }^{6}$ László Németh analyzed the connections between brilliance and an allegedly melancholic character. ${ }^{7}$ Mária Rónay, in her article $A$ rejtélyes Beræssenyi Dániel - a pszichopatológia tükrében (The mysterious Dániel Berzsenyi - In the light of psychopathology), described his poetic career as the work of a man who was a sickly father who suffered from anxiety and was also stingy and, in his advanced age, anti-Semitic. ${ }^{8}$ Henriette Szirmay-Pulszky, in her monograph entitled Genie und Irsinn im Ungarischen Geistleben, classified Berzsenyi as schizoid, and concluded, on the basis of his alleged physical and spiritual characteristics, that he was a psychopath prone to melancholy and was deeply depressed.9 The list goes on and on. One almost gets the impression that Berzsenyi was looking for trouble, as if, even if unwittingly, his life goal had been to gnaw at his own soul and provide work for psychoanalysts, as if the physician and historian Sándor Puder's following statement made in 1933 were true: "Real literature is analytical, and it was already so at the time when psychoanalysis was nowhere to be found. Even as early as at that time, [Berzsenyi] unconsciously used the method of psychoanalysis in his analytical, psychologizing literature."10

I disagree with this. If we stick to Dilthey's original idea, i.e., if we seek not only to define, build out of fragments, or develop the inner ingredients of subjects from an inner meaning (psychology) but also to define the comprehensive framework and meaning (Geistesgeschichte) into which the individuality fits, it does not suffice to provide a psychological portrayal of Berzsenyi. And, although the inner psychological meaning of a personality cannot be uncovered in enough depth in my opinion, no matter how hesitant we are to take the slippery route of psychologization, I will attempt to reconstruct Berzsenyi's disease, or more specifically, one of his mental illnesses.

\footnotetext{
5 Halász, "Berzsenyi lelkivilága."

6 Fejtô, "A 'sinlődő álóé."

7 Németh, Beræsenyi Dániel, 87-129.

8 Rónay, "A rejtélyes Berzsenyi Dániel."

9 Szirmay-Pulszky, Genie und Irsinn im Ungarischen Geistleben, 20-22.

10 Puder, Mit köszönhet ą irodalom az orvostudománynak, 55.
} 
Berzsenyi ceased all communication with Ferenc Kazinczy in 1817, following Ferenc Kölcsey's critical review. He simply did not write to him anymore. Kölcsey was Kazinczy's student, and when Berzsenyi asked about him, Kazinczy defended him. Thus, the issue at hand was one of human relationships, as is documented in the correspondence until the friends stopped communicating with each other. Three years later, in the winter of 1820, an old friend of theirs notified Kazinczy that Berzsenyi was in Sopron: "We only rarely see each other. He, as he says, became sick two years ago and was mistreated; the consequence of which became one of the greatest building blocks of his hypochondria, which not even the Buda spa could improve, but only the Füred one, or rather, sour water. Now, he says he is in passable condition, but he dare not read: he spends his time in the theater and the café, and we also visit each other sometimes."11 Possibly after having communicated with this common friend, Berzsenyi grabbed his pen and wrote one of the letters which is cited the most often in the secondary literature on Berzsenyi.

Overall, we do not know much about what Berzsenyi was doing in Sopron. We also do not know too many details about his illnesses beyond what he (and their common friend) claims, namely that he was plagued by bypochondria and that he visited the baths in Buda and Balatonfüred. The contents of the letter are startling and unexpected, and it also rhetorically expresses the state he said he was in. The letter reads as follows:

Dear Sir,

You did not visit your dying friend; and behold, his shadow shall come upon you. His shadow, I say, because the soul you once bothered with so much is no more. Yes, Dear Sir, even though I am beginning to live again, my soul has long since died, and it has been replaced by a new unknown soul, dark and cold as night, and still as the grave. The horrific disturbance that has turned my whole nature upside down could have had no other result than this half-death. And since this halfdeath can easily become complete, and since my headache still often tolls the bell of death in my ears, I did not want to die as your imagined enemy but wanted to let you know that whatever crime I committed against you, I did it amidst the deepest hypochondria. For the same reason, pity me or laugh at me as you please, but do not hate me, rather attribute everything to my cruel illness, which has often made me halfcrazy and half-mad. The causes of my illness were a quinine-treated inflammation of my gallbladder and a dangerous fall in which my

11 “János Kis to Ferenc Kazinczy, Sopron, December 10, 1820.” In: Kazinczy, Levelez̧ése, vol. 17, 299. 
shoulder was dislocated, and my shoulder blade was fractured, and my head also suffered a large bruise, all of which caused me to be confined to bed for six months. The rude criticism [by Kölcsey] perhaps also belongs here, which provoked me into thinking in a state when I was most incapable of doing so. You can imagine what a tremendous job it was for me to aestheticize with a confused head, an angry heart, and without any books, even though I have never read aesthetics or poetry other than Rájnis's Kalauz (Guide to poetry). Now I'm reading and smilingly reviewing my feeble attempts of the time. You should smile at this, too! This is how I have always been: I did not think I needed to study, and therefore I did not study. ${ }^{12}$

A friend of yours from Pest once told me that you would not even be capable of writing a scholarly work like Kölcsey's critique. Now I think you could not write such a rude one. But whether you wrote it or not, it does not matter to me now. You could have had dark hours like I have, and you were free to treat me like all my friends throughout my life; you did nothing new to me. This is how I now feel about Kölcsey, whose abuse I would tolerate just as much as I have tolerated that of Mondolat, had I not written that hypochondriac countercriticism; ${ }^{13}$ but since I did write it, I must also write another, for it would be quite a ridiculous conclusion to my literary life. This is also how I feel about Thaisz, Szemere, and Vitkovics, who mocked me to my face in my miserable state, ${ }^{14}$ and who found it appropriate to trample on my ashes even in the Tudományos Gyüjtemény (Scientific collection); this is how I feel, I say, because I know very well that those who torture the pitiful with such insults will be helped by neither rhubarb, nor the sour water of Füred, nor my text.

And so, Dear Sir, I live and write again, and behold my very first letter is Yours. Accept my cold hand once again with the calm soul with which I offer it to you. I am well aware that there could be no reason, no desire, for you to fraternize with a deteriorated hypochondriac; but it is not friendship I am coming for, since, believe me, my resignation is also complete both towards you and towards the whole world, and my heart desires, knows no good but the serenity of this resignation; I just wanted to let you know that my state has improved so that you think better of me and do not consider me your enemy, and do not hate me.

12 Berzsenyi suggests that he wanted to respond to Kölcsey's criticism, for which he had to study aesthetics. Rájnis's Kalauz is a collection of poetic examples, and so it is not a regular work on aesthetics. 13 Mondolat was an infamous pamphlet published in 1813 which criticized both Kazinczy and Berzsenyi in a satirical manner. Countercriticism was the first version of Berzsenyi's response to Kölcsey. Berzsenyi withdrew his text, but the manuscript reached Kölcsey, who published it in his journal. This was not nice of him. In any case, Berzsenyi refers here to his bad reputation after the incident.

14 András Thaisz, Pál Szemere, and Mihály Vitkovics were followers of Kazinczy and friends of Kölcsey. 
Be fortunate, be happier than I am, and do not experience the misery I have endured. ${ }^{15}$

We are between life and death, in a paradoxical half-death: still in this world but already beyond the death of the soul. This is a surprising transmutatio: the immortal soul is already dead, but the mortal body is still alive. And the dead soul is replaced by another, possibly death itself, with its metaphors crowding around it: shadow, darkness, cold, night, the grave, the cold hand. Very much like the protagonists of sensible epistolary novels, Berzsenyi eliminates the difference between life and death, between body and soul. On the one hand, life has become just as problematic as death through his illness; on the other, by this era, the physical and spiritual symptoms of an illness appeared as each other's complements. It is no coincidence that the poet first lists his physical symptoms and returns to his spiritual problems in the following sentence. Much as the body does not exist without the soul, health does not exist without illness. István Mátyus, the author of a popular medical handbook of the era, a sixvolume edition on dietetics, writes "people in perfect health are quite rare in this world, and if someone does manage to step up to this state for an hour or two, he cannot stay there for long, due to the miraculous structure of nature. Instead, good health starts to deteriorate, so that we have to extend health to certain limits." From the eighteenth century on, the natural state was not the healthy one, i.e., health was not a clearly defined, enclosed whole, "there are smaller and larger illnesses, but there is also lesser and greater health."'16

Part-whole relations also disrupt narration, and metonymic story-building is disrupted in the letter, with metaphorical relations foregrounded instead. This is again a popular method of the epistolary novels of the era: frustrated and fragmented narration. The metaphorical construction of the text (text built on some image and the associations surrounding it) is also present here (through the metaphors of death); however, the train of thought is not coherent, and consecutive paragraphs are only loosely connected to each other (although there is no switch between the topics). The frequency of salutation and the deixes pointing to the addressee are of course not surprising at all, sensibility also viewed openly owning up to one's feelings and displaying uncontrolled virtuous impulses coming from deep down as an anthropological feature, which also meant the fragmentation of the text.

15 “Dániel Berzsenyi to Ferenc Kazinczy, Sopron, December 13, 1820.” In: Berzsenyi, Levelezése, 532-34.

16 Mátyus, Ó és új diaetetica, 40. 
At times we almost reach incomprehensibility. For example, in the break in thought between the second and third paragraphs: while in the first he dismisses his friendship with Kazinczy, among others, he begins the second by addressing Kazinczy as a friend. Immediately after the impossibility of recovery, only signaling the break in his thought by a line break, he writes about his resurrection: the notion of death alternates with the possibility of a fresh start throughout the letter. Complete death does not take place because it would also mean the end of the self-narrative, and the writer and narrator (uniquely, these two are one and the same here) do not wish that. He does not wish for his story to end with a sick hypochondriac text in front of the public, and so he first needs to write the missing ending to the novel of his life. The act of writing is thus only an excuse for self-fashioning; in other words, a kind of fictitious, imaginary life and a lived life, assumed to be real, are all mixed up here. Evoking the other also directs attention to the self in the letter. Friendship becomes the territory of absence, and the letter may make up not only for the lack of personal encounters but also for the avoidance thereof. Namely, imitating an in-person meeting quickly turns into an analysis of resignation. Resignation thus deletes notions of friendship and animosity and enters the same intermediate borderland located between body and soul, life, and death.

So far, I have listed the characteristics of the Berzsenyi letter that connect it to the popular epistolary novels of the era in terms of narrative technique. However, at the beginning of the paper, I set out to talk about Berzsenyi's disease and mental illness, so let us thus leave the territory of aesthetics and enter dietetics.

\section{Hypochondria}

The second half of the eighteenth century was the heyday of medical anthropology, and around this time, philosophical anthropologies were also written by physicians for physicians in large quantities, thus man becomes a patient in a representative manner through anthropological nosologies and the birth of clinics. This is best illustrated by the large number of medical handbooks written for laymen in the second half of the eighteenth century, including in Hungarian. ${ }^{17}$

17 In the wake of the medical reform measures launched in the mid-eighteenth century, both the Habsburg government and physicians realized that disseminating knowledge in the vernacular could improve health consciousness, foster trust in "official" medical practices, and consequently advance the overall health of 
If we ask what hypochondria could have meant, at least roughly, in the first decades of the nineteenth century, we will not receive a clear answer. Burgeoning medicine offers so many different solutions; it describes the different symptoms in great detail (often through interesting stories), processes so many different medical ideas and provides so many seemingly sure-fire formulas that we can easily encounter problems upon evaluating a disease.

István Benedek, in his short essay on Berzsenyi's melancholy, wrote about the difficulties of interpreting hypochondria in 1982. "Just as it will not be easy to orient oneself in the substance and interpretations of today's schizophrenia in the next century, erstwhile hypochondria is also a large umbrella. It is related to what today lies behind psychopathy, neurasthenia, psychasthenia, neurosis, and many other, less popular expressions, it is related to apathy, melancholy, amentia, and the expression 'dementia', used in French-speaking areas. Instead of the many foreign expressions, it is easier to approach it through a simpleminded definition: a melancholic affliction that sinks you into inertia. It is not insanity, not a reaction to external circumstances, but an enigmatic constitutional characteristic, God's curse."18 Although these various types of madness may not be as blurred in early modern times as Benedek claims, ${ }^{19}$ hypochondria is quite a "large umbrella," and accordingly, a popular topic of contemporary medical literature. A German historian of medicine, for example, counted that in the Jena Journal der praktischen Arzneykunde und Wundarzneykunst edited by Christoph Wilhelm Hufeland, one of the best-known medical professors of the time, ten percent of the literature on nosology is on hypochondria. ${ }^{20}$ This is a high ratio, and although it is equally interesting, and I do not have precise data on the Hungarian material, the four Latin-language dissertations published in Hungary that discuss hypochondria exclusively, and the chapters of the popular medical handbooks that discuss hypochondria show that the Hungarian medicalanthropological discourse was also keenly interested in the issue.

In the case of hypochondria, even the classification of the disease in terms of nosology is difficult to determine. This is because we cannot disregard the

the population. From the 1780s onwards, as part of the general tendencies of the medicalization of society, psychological knowledge was gradually filtered into medical books written in the vernacular to rationalize and normalize everyday experiences with mental illnesses. See Kovács, "Lélektudományos ismeretek közvetítése.”

18 Benedek, "Berzsenyi búskomorsága."

19 See for example Immanuel Kant's classification: Kant "Versuch."

20 Schwanitz, Die Theorie der praktischen Medir̨in, 27. Cited by Birtalan, "A felvilágosodás mentálhygiénéje," 49. 
fact that initially, based on the typological classification of ancient humoral pathology, melancholy, which had enjoyed a long career in the history of European medicine and culture, also included hypochondria. Namely, Galen sees the origins of melancholy as lying in a disorder of the bypochondrium, the upper part of the abdomen, and this connection seemed logical until the beginning of the eighteenth century. ${ }^{21}$ For example, Ferenc Pápai Páriz still wrote about "Hypochondriaca Melancholia" in his popular medical handbook Pax Corporis in $1690 . .^{22}$ Since "in the age of Reason," a shift of emphasis within the concept of hypochondria can be detected, i.e. "a dynamics of the corporeal space gives way to a moral theory of sensitivity," 23 we can observe how hypochondria and its related feminine disease, hysteria, replaced the pair of melancholy and mania, and how these structures operated and divided in parallel with each other. However, according to Michel Foucault, "physicians of the classical period did try to discover the qualities peculiar to hysteria and hypochondria, but they never reached the point of perceiving the particular coherence, that qualitative cohesion which gave mania and melancholy their unique identity." ${ }^{24}$ Hypochondria cannot be defined or located, and it is difficult to specify. For example, in Immanuel Kant's 1764 treatise Versuch über die Krankheiten des Kopfes we find the following: "The hypochondriac has a disease which, in whatever place it is chiefly located, is nevertheless likely to wander intermittently through the nervous system to all parts of the body." 25 Its seat cannot be located, and it is in constant motion and, thus, difficult to catch.

Let us instead allow Foucault to classify and meticulously analyze "figures of hypochondria" 26 and examine the function this disease plays in the patient's life. Through his disease, the hypochondriac enters the territory between body and soul, life and death, a place that cannot be detected. First, this disease makes

21 Földényi, Melancholy, 49-55.

22 Pápai Páriz, Pax Corporis, 239-40.

23 Foucault, History of madness, 286. The popularity of hypochondria and hysteria in Foucault's description is just one sign of the end of the Age of Reason (l'âge classique). (Foucault's l'âge classique is ahead of the era I am studying, in Racine's century.)

24 Ibid. 280.

25 Kant, "Versuch," 266.

26 Foucault, History of Madness, 277-96. Eighteenth-century medical discourses were characterized by the inconsistency and eclecticism of the concepts of health and disease, such as mechanistic theories, animism, vitalism, neurophysiology, and -pathology. Consequently, the place and function of the soul, its impact on the human body and vice versa, or the boundaries of different mental disorders or rather clusters of symptoms were hard to define. On these discourses see: Porter, "The Greatest Benefit to Mankind," 245-303. 
life similar to death, which is no surprise after having read Berzsenyi's letter. This problem is so central that the Hungarian István Mátyus, for example, illustrates the difficulties of defining life with the frequent phenomenon that happens to hypochondriac men and the hysterical women related to them: "What life is, is not as easy to determine as it seems at first glance. Namely, many died a long time ago who were thought to be alive by society; at the same time, many lived who were thought to be dead for sure. Examples of these are the many bysterical women and bypochondriac men who, having fainted [...], hardly seemed to be alive, what is more, oftentimes seemingly having died completely, they were placed under the dissecting knife or in the coffin; but after some time, they came back to life on their own or with the help of some external tool, much to everyone's surprise." ${ }^{27}$ The comatose and the hypochondriac are closely related to each other. On the other hand, the close connection between the body and soul also surfaces in hypochondria, and in this period, probably no disease of the mind existed that would be independent of particular physical processes. The bypochondrion (in Latin: hypochondrium), as mentioned above, is the upper part of the abdomen, the right and left part of the abdominal cavity enclosed by the arches of the diaphragm. This was the part of the body where diseases of the mind had been located since Galen. It is still a widespread view in popular medicine to this day that different gastric problems, primarily stomach ulcers or irritable bowel syndrome, are consequences at least in part of an overwrought, stressful life. In his popular handbooks on dietetics, Mátyus looks for the causes of various diseases in the incorrect flow of different humors. Yet, if hypochondria is a disease that also affects spiritual life, the humors also reach the mind; in other words, the direct causes of the illness are the "frequent strong spasms in everyone's weakened internal parts, driven by the thickened, rancid humors that have collected and settled in them, which wander around the whole body and cause a sudden multitude of changes both in the body and the mind. Its more distant causes, on the other hand, are all that weaken the stomach, thicken and sour the blood, and do not allow it to flow freely inside the internal parts." 28 The internal space of the body is freely permeable, obstacles and obstructions are created at different points, different humors slow down and decrease the speed of life functions and disturb the quality of life, ${ }^{29}$ for the sensible person pax corporis is already an unattainable ideal. Christoph Wilhelm Hufeland recounts

27 Mátyus. Ó és új diaetetica, vol. 1, 16-17.

28 Mátyus, Diaetetica, vol. 2, 1766, 363.

29 See Zacharides, Dissertatio, 16. 
one of the teachings of Dutch professor Herman Boerhaave from Leiden, who lived approximately one hundred years before him and remained a dominant figure in European medicine in the eighteenth century: "Boerhaave says that the blood that flows onto the brain makes people see bloody ghosts and rainbows." 30 This means that physical and mental illnesses are closely related, and we cannot separate medicine from psychology. As Christian Friedrich Richter put it very eloquently at the beginning of the eighteenth century, "The matter or the body is attracted by the soul through the union to such an extent, mixes with it so much, so to speak, as if the soul became material-like or corporeal, and as if the body became spiritual." ${ }^{31}$

Material and spiritual things, these two good friends, alternated between tightening and loosening their friendship, and they also drifted apart from each other after a while. This is how hypochondria slowly turned from an illness of sensibility into an illness of the imagination. This change can also be detected in Hungarian popular medicine. For example, in Sámuel Köteles's Philosophiai anthropologia (Philosophical anthropology), published posthumously in 1839 (and written some time during the 1820s), these two diseases still appear after each other, but they are already separate diseases. As he writes about hypochondria, "This disease is a fear, restlessness, and despondency resulting from some impending indeterminate harm. The hypochondriac indeed experiences some illnesses which originate from the irregularity of bodily functions, especially in the bowels. These illnesses are not such that some serious illness or even death would result from them, but the lively imagination of the hypochondriac nurtures them. Thus, hypochondria becomes the source of many diseases. ${ }^{32}$ This is how an imaginary invalid becomes a hypochondriac (Molière's Argan is not yet a hypochondriac but merely a malade imaginaire), and by the second half of the nineteenth century, imaginary illness also became an illness of its own. The expansion of nosological literature first resulted in the appreciation of hypochondria, while soon afterwards, being unable to earn its own place within the framework of this system, it was devalued into a meta-disorder. This place for hypochondria was created by the overgrowth of the system to which it owed its existence. It is no coincidence that hypochondria, i.e., the disease that was looking for its place in the human body, appeared as some kind of

30 Hufeland, Az ember' élete, 172.

31 Richter, Erkenntniss des Menschen, 80.

32 Köteles, Philosophiai anthropologia, 216. 
civilizational, particularly urban disease. ${ }^{33}$ While Hufeland could still make fun of one of Boerhaave's students without mentioning hypochondria, because he literally loved the Dutch professor's teachings and was thus "an animated lesson," 34 the Viennese physician, Baron Ernst Feuchtersleben already calls hypochondriacs "the volunteers of medicine," "who have dug themselves into the entire pathology, who write themselves prescriptions from books." ${ }^{35}$ It was somewhere around this time when the context of Dániel Berzsenyi's illness, to be interpreted in the discourse of sensibility, became blurred, and this is where the psychological descriptions of modernity floundered.

\section{Constipation}

Or maybe that context did not disappear completely. A common characteristic of disease and related mental illnesses, which continued for a long time, is that mental instability (the illness of the head or the heart, depending on the person) and abdominal (constipation-related) illnesses are linked. In 1830, József Horvát, a doctor of medicine and arts, translated Franz Richter's book into Hungarian and rewrote the parts on hemorrhoids and related illnesses, including hypochondria. He discusses the abdominal consequences of madness in the chapter Az aranyérnek gerjesz̨ő́ vagy távolabb okairól (On the inflicting or other causes of hemorrhoids). He thinks it is obvious that no explanations are needed: "Everyone knows the influences mental illnesses have on health in general and on the functioning of the organs of the lower body in particular so well that we should not say anything it." According to Horvát-Richter, "people prone to anger and irritation already suffer from illnesses of the lower body anyway, or at least they are on the verge of thereof, and so they are also more or less likely to have hemorrhoids," while the more hidden mental illnesses, the so-called "discouraging affections," such as worry, sadness, fear, listlessness, timidity (all of these are characteristic of hypochondria), also influence processes in the lower body, even if more slowly. However, these do not cause any serious physical problems, only digestive disorders and "obstructions": "These, weakening

33 See for example Zay, Falusi orvos pap. For the philosophical-sociological context of melancholic diseases see Lepenies, Melancholie und Gesellschaft, 76-114.

34 Hufeland, Az ember' élete, 175.

35 Feuchtersleben, Die Diätetik der Seele, 71. Cited by Birtalan. "A felvilágosodás mentálhygiénéje," 53. 
the circulation of blood, are particularly harmful to digestion, and they cause obstructions especially in the abdomen." 36

The obstructions disrupt the entire body. For example, in Berzsenyi's letter to Kazinczy, he also mentions his headache: "my headache still often tolls the bell of death in my ears." Franz Schedel (a Hungarian literary historian known as Ferenc Toldy), in his lecture notes on dietetics prepared for his medical students, still links headaches to gastrointestinal disorders in 1839: "Constipation causes wind and cramps, and if it lasts, it obstructs the unimpeded circulation of blood in the lower body and causes it to amass in some parts and causes aches, more specifically, obstructions towards the head: headaches. ${ }^{\text {”37 }}$ In Sámuel Rácz's 1776 Orvosi oktatás (Medical training), it is sadness that is linked to these physical processes, again without mentioning hypochondria: "Those who often suffer from stomach cramps are glum, sad, withdraw from merry amusements, become weak, are happy to sit, become pale and have difficulty breathing whenever they have to move: the stomach is often obstructed; the digested matter is formed into pellets." ${ }^{\prime 3}$ A little headache, some sadness, constipation and blockages (obstructions), and occasionally unexpected wind are all not so fatal here anymore, and although nosology has changed here and there, the interfaces and contacts within the system have remained the same.

In my opinion, by emphasizing hypochondria, Berzsenyi provides Kazinczy with a key to reading his letter. He offered it not, or not only, as some weak explanation as to why he committed his crime (that he had written his Countercriticism), rather than offering a way to read his sensible epistolary novel, in which he is also a character. In illness, the border between life and death dissolves, while in the illness of hypochondria, it is the border between physical and mental illness that dissolves. It is no coincidence that Berzsenyi's (the narrator's, the hero's) physical injuries (overturned car, broken bones) and mental injuries (confused head, angry heart, and ignorance) appear next to each other, even if it is somewhat unexpected. The energy of the opposites straining on each other (I live and die, write, and do not write, selfless friendship and no friendship, scholarship and amateurism, etc.) can be channeled into

\footnotetext{
36 Richter, Tanácsadó, 43.

37 Schedel, Dieteica' elemei, 56.

38 Rácz, Orvosi oktatás, 128. Rácz later translated and rewrote Baron Anton Störck's Praecepta medico practica (1776), in which the famous Viennese doctor tried to complete the system with a list as detailed as possible by mixing different theories. He collected eight possible causes of melancholy (one of which is "hypochondriac disposition" and another "abdominal congestion," but he also includes, for example, scabies, sadness, or "device defects" in the brain). Störck, Orvosi praxis, 469-70.
} 
hypochondria. Analyzing Johann Ulrich Bilguer's 1767 essay entitled Nachrichten an das Publikum in Absicht der Hypochondrei, László F. Földényi concludes that existence thickens around hypochondriacs, but just like in the case of all vortices, everything turns into nothing beyond a certain point. ${ }^{39}$ If Berzsenyi is heading towards something in his letter, it is the serenity of resignation. The complete dissolution and elimination of opposites.

\section{Ethics}

Berzsenyi's letter is an unfriendly letter to an old friend: the salutation is formal ("Dear Sir"), Berzsenyi floats the idea that it was in fact Kazinczy who wrote (or at least suggested) Kölcsey's criticism, etc. In the second paragraph, friendship is presented as a possible opposite to hypochondria. In social life, problems are dissolved, while loneliness creates a sense of absence, and in loneliness, the balance of the body and soul is disturbed. However, a disloyal friend punishes not only us but themselves as well. According to Berzsenyi, "those who torture the pitiful with such insults will be helped by neither rhubarb nor the sour water of Füred, nor my text," i.e., the disease will catch up with them too. Namely, discarding one of the main spiritual virtues, i.e., friendship, is one of the main symptoms of hypochondria (as this is what the next paragraph is about, i.e., how he replaced Kazinczy's friendship with resignation). And it is also probably no coincidence that he recommends the water of Füred and rhubarb to András Thaisz, Pál Szemere, and Mihály Vitkovics. Kölcsey agrees that this is no coincidence. He was familiar with the text of the letter, and this is where he sensed the biggest insult: "That he [Berzsenyi] believed that he did not have to study, that he is already studying and he wants to replace his hypochondriac Countercriticism with a better one, that he considers Thaisz, Vitkovics, and Szemere as people who mocked him to his face and who trampled on his ashes, and when talking about them, he keeps mentioning rhubarb and Füred water: these, my dear friend, are the words of deepest hypochondria. But this hypochondria comes not only from the quinine-treated inflammation of the gallbladder, or from tipping over, it is feared that its biggest lair is in the mistaken idea of the pretended invincibility of genius." ${ }^{40}$ But why exactly are these the deepest words of hypochondria?

39 Földényi, Melancholy, 200.

40 “Ferenc Kölcsey to Pál Szemere, Cseke, April 6, 1823.” In: Kölcsey, Ferenc. Levelezés II, 49-50. 
Rhubarb is an old medicine, and in Házi orvos szótárotska (A small dictionary of home medicine), a compilation of sixteenth-century herbaria written by the infamous Hungarian charlatan of the time, Mihály Nedliczi Váli, it is primarily recommended as a remedy for stomachache; what is more, boiled in the juice of Hungarian aszú grapes, it not only eases the dryness of the throat, but it can also be used to treat dysentery, bloating, stomachache, hiccupping, and of course, melancholy. ${ }^{41}$ And mentioning the Füred water which was considered to be a medical miracle cure in the era in question, may also be of significance. ${ }^{42}$ The different sour waters and baths often served as treatments for various illnesses of obstruction, such as constipation and the hemorrhoids related to it, as well as melancholy and hypochondria. ${ }^{43}$ The best-known of these is probably the Füred water, which Hungarian physician János La Langue's book on waters recommends for curing the most diverse illnesses of constipation, including hypochondria: "this water has strengthening, releasing, and digestive powers, so it helps the weakness of the stomach and the abdomen, third and fourth-day chills, blockages of the liver, spleen, kidney and uterus, and hypochondria." ${ }^{44}$

Does Kazinczy understand the language of hypochondria? In a letter written seven years later, he enthuses to an aristocrat friend of his: "Your letter would horrify me with the news that your soul has been plagued by hypochondria. But you lament about it in such a beautifully written letter that if hypochondria was capable of making one write in such a way, I would ask the Gods to release it on me as well; not even the healthiest soul can write such a letter." ${ }^{35}$ Hypochondria is thus characterized as a condition which brings up something that had been

41 Váli, Házi orvos szótárotska, 141. Mihály Váli was a notorious charlatan, almost summoned before the Milan Inquisition for befriending the devil, although he was patronized by influential Hungarian aristocrats. Count György Erdődy even recommended him to the ruler, and he eventually became Prince Miklós Esterházy's court physician and accompanied him on his western tour. See Magyary-Kossa, Magyar orvosi emlékeke, 98-99. The plagiarized works: Beythe, Fives-könür; Melius, Herbarium.

42 At Maria Theresa's instructions, Henrik Crantz prepared a report on mineral waters in Hungary, where the water of Füred was given a prominent role (Cranz, Analyses, 88). Under the instruction of Joseph II in 1782, Jakab Antal Winterl and Ignác Ádám Prandt prepared a mineralogical report (see Zákonyi, Balatonfired, 305-11). In his decree of January 18, 1784, Joseph II regulated the consumption of sour waters (Linzbauer, Codex Tomus III., Sectio I., 70-80). After that, the introduction of one royal decree after another indicates a growing interest in mineral waters (between 1783 and 1800, Linzbauer collected 27 decrees regulating the use of medicinal waters in Hungary, ibid. 930). On the waters of Füred, see Daday, "A régi Balatonfüred."

43 It recommends spas against strains and melancholy e.g. Csapó, Orvosló könyvetske, 21-25; Frank, Az orvos mint Házi-Barát, 75.

44 La Langue, A’ Magyar Országi Orvos Vizekeröl, 74-75.

45 “Ferenc Kazinczy to Count József Dessewffy, January 10, 1828.” In: Kazinczy, Levelerése, vol. 20, 452. 
closed off below, much as the language of Foucault's déraison, or pain, creates an independent discourse in the era of sensibility. ${ }^{46}$ In his response to Berzsenyi dated 18 January 1821, Kazinczy rejoices over his fortunate recovery from the illness and the restoration of the balance of his mind: "Truth and time finally lift the fog, and what is clear is known as clear." ${ }^{47}$ This is the paradox of hypochondria: the more we want to help the patient, the deeper we push them. Everything can be reversed. We may even behave ethically towards our patient in the long run; at the same time, this cannot be the method to treat the symptoms that are currently perceived.

The end of their friendship is the beginning of the disease. In Berzsenyi's 1820 letter, we can first read how true friends (Kazinczy and his followers in Pest) betrayed Berzsenyi and pushed him into illness, and then how now there is no point in making friends with him: what is more, it is impossible to make friends with him anymore. The disloyal friends may suffer all that the one they betrayed had to suffer. Kazinczy's response letter wants to resolve this tension, and as a good friend, he consoles him, since patients always need hope: "You call your state a half-death. Your letter exposes this claim as untrue, because you did not write more enthusiastic ones in your healthy days either, life and strength sparkle within. I would be inconsolable if this hope did not revive you. Nec dis amicum est, nec mihi te prius obire, my dear friend."49 The Latin quote comes from the first strophe of Horace's ode written to the sick Maecenas (Carm. 2,17), which has been considered the ode of intimate friendship for centuries, and in the next strophe of which Horace attributes half of his soul to his friend. In other words, Maecenas-Berzsenyi's "half-death" would also bring death to Horatius-Kazinczy: "ibimus, ibimus, / utcumque praecedes, supremum / carpere iter comites parati." Their friendship, their shared astrological sign ("utrumque nostrum incredibili modo / consentit astrum") imposes responsibility on both friends, if one of them is sick, their illness is also shared (as the parallel stories of the last three strophes of the Horace ode suggest), and a shared sacrifice is necessary: "Reddere victimas / aedumque votivam memento: / nos humilem feriemus agnam."

\footnotetext{
46 See Rey, The History of Pain, 89-131.

47 “Ferenc Kazinczy to Dániel Berzsenyi, Széphalom, 1821.” In: Kazinczy, Levelezése, vol. $27,364$.

48 The often cited ancient example of this behavior comes from a letter of Cicero to Atticus: "aegroto dum anima est, spes esse dicitur." Ad Att. 9,10,3.

49 “Ferenc Kazinczy to Dániel Berzsenyi, Széphalom, 1821.” In: Kazinczy, Levelezése, vol. 17, $363-64$.
} 
The end of their friendship is the beginning of the disease. The flip side of this may also be true: friendship is a balm for illness. It is literally medicine. Sir Francis Bacon writes this on friendship: "We know diseases of stoppings, and suffocations, are the most dangerous in the body; and it is not much otherwise in the mind; you may take sarza to open the liver, steel to open the spleen, flowers of sulfur for the lungs, castoreum for the brain; but no receipt openeth the heart, but a true friend; to whom you may impart griefs, joys, fears, hopes, suspicions, counsels, and whatsoever lieth upon the heart to oppress it, in a kind of civil shrift or confession." ${ }^{50}$ The constipations and stoppages of the body orifices and the constriction of the soul happen parallel with each other, and a good friend can resolve our problems. However, the hypochondriac does not have friends. Kazinczy also knows what can be read in a popular medical book, that "sad, listless persons need to be cheered up, and we should try to take them to merry companies," but also that "such patients [...] are broody, fearful, skittish, mistrustful, and they often become quite dejected if someone contradicts their foolish opinions or does not believe them.." ${ }^{51}$ Kazinczy wishes to relieve Berzsenyi by listening to him, but an obstruction that he cannot unplug stands in his way.

\section{$* * *$}

When Berzsenyi chooses a literary form for his letter (the sensible epistolary novel), he consciously enters a medical discussion in which aesthetics and morality are interconnected. In this essay, I attempted to describe the narrator's illness with the help of the contemporary practice of medicine and anthropology, and I eventually located its place in a moral-ethical discourse. I concluded that these three seemingly different areas are linked very closely, and those who only reconstruct Berzsenyi's psyche can only enrich the psychological literature of their own horizon, while they will necessarily draw the wrong conclusions, since Dániel Berzsenyi himself cannot lie on the psychoanalyst's couch. I tend to believe the cautionary note of the abovementioned Christian Friedrich Richter, who warned that those who "wish to place the body only in the jurisdiction of medicine and the soul in that of the humanities and place intellectual life in the theological faculty are wrong." 52

50 Bacon, "Of Friendship," 113-14. Contemporary Hungarian translation: Bacó, "Gondolatjai."

51 Frank, Azorvos mint Házi-Barát, 75, 73.

52 Richter, Erkenntniss des Menschen, 412. 


\section{Bibliography}

Bacon, Francis. "Of Friendship.” In The Essays or Counsels, Civil \& Moral, 112-23. London: T. N., 1673.

Bacó, Verulámi Báró. "Gondolatjai külömbféle tárgyakról” [Thoughts on different subjects]. Felső Magyar-Országi Minerva 2, no. 10 (1826): 905.

Benedek, István. "Berzsenyi búskomorsága" [Berzsenyi's melancholy]. Egészségügyi dolgozó 25, no. 10 (1982): 4.

Berzsenyi, Dániel. Levelezése [Correspondence]. Edited by Gergely Fórizs. Budapest: EditioPrinceps, 2014.

Beythe, András. Fives-könüv [Herbarium]. Vivaratt: Manlius, 1595.

Birtalan, Győző. "A felvilágosodás mentálhygiénéje külföldön és Magyarországon” [The mental health of the Enlightenment abroad and in Hungary]. Communicationes de historia artis medicinae 102-104 (1983): 45-74.

Crantz, Heinrich Johann Nepomuk von, Analyses Therm. Herculanarvm Daciae Traiani. Vienna: Joseph Kurzböck, 1773.

Csapó, József. Orvosló könyvetske, melly betegeskedō szegény sorsu ember számára és hasznára készült [Medical booklet which was created for the use and benefit of sickly and afflicted people]. Pozsony-Pest: Füskuti Landerer Mihály, 1791.

Daday, András. "A régi Balatonfüred történetéhez (1815-1818)" [On the history of old Balatonfüred, 1815-1818]. Communicationes de historia artis medicinae 44 (1968): 117-24.

Dilthey, Wilhelm. "Ideen über eine beschreibende und zergliedernde Psychologie (1894)." In Gesammelte Schriften. V. Band, Die geistige Welt. Einleitung in die Philosophie des Lebens: Erste Hälfte: Abhandlungen zur Grundlegung der Geisteswissenschaften, edited by Wilhelm Dilthey, 139-240. Stuttgart-Göttingen: B. G. Teubner-Vandenhoeck \& Rupprecht, 1894.

Fejtő, Ferenc. “A 'sinlődő álóé’: Berzsenyi Dániel halálának századik évfordulójára” [The 'suffering aloe': For the hundredth anniversary of Dániel Berzsenyi's death]. Szép Szó 1 (1936): 9-18.

Feuchtersleben, Ernst Freiherr von. Die Diätetik der Seele. Wien: Carl Gerold, 1851.

Foucault, Michel. History of Madness. Edited by Jean Khalfa, translated by Jonathan Murphy, and Jean Khalfa, foreword by Ian Hacking. London: Routledge, 2006.

Földényi, László F. Melancholy. New Haven-London: Yale UP, 2015.

Frank, Lajos Fridrik. Az orvos mint Házi-Barát vagy egy orvosnak az atyák-'s anyákhoz intézett barátságos oktatásai, minden gondoltatható nyavalyákeról akármelly korban [Physician as a family friend, or the friendly teachings of a physician to fathers and mothers, on 
all conceivable ailments in any age]. Second, revised edition. Translated by József Horvát. Pest: Hartleben C. Ádolf, 1830.

Greenblatt, Stephen. Renaissance Self-Fashioning: From More to Shakespeare. Chicago: University of Chicago Press, 1980.

Halász, Gábor. “Berzsenyi lelkivilága” [Berzsenyi’s psyche]. Symposion 2 (1926): 77-107. Hufeland, Christoph Wilhelm. Az ember' élete meg-hoszszabbitásának mestersége [The art of prolonging life]. Translated and expanded by Mihály Kováts. Vol. 1. Pest: Patzko Ferenc, 1799.

Kant, Immanuel. “Versuch über die Krankheiten des Kopfes.” In Kants Werke. Vorkeritische Schriften II. 1757-1777. Gesammelte Schriften, vol. 2, 259-71. Berlin: Reimer, 1905.

Kazinczy, Ferenc. Levelezése [Correspondence]. Edited by János Váczy. Vol. 1-21. Budapest: Magyar Tudományos Akadémia, 1890-1911.

Kovács, Janka. "Lélektudományos ismeretek közvetítése a magyar nyelvű orvosi irodalomban a 18. század második felében" [Mediation of psychological knowledge in the late eighteenth-century medical works in Hungary]. In Fenntartható tudomány. Hagyomány és újrahasznositás a felvilágosodás elōtt, edited by Ildikó Mária Bene, Annamária Molnár, Kata Ágnes Szűcs, Csilla Virág, and Márk Vrabély, 121-47. Budapest: Reciti, 2020.

Kölcsey, Ferenc. Levelezés II [Correspondence II]. Edited by Zoltán Szabó G. Budapest: Universitas, 2007.

Köteles, Sámuel. Philosophiai anthropologia [Philosophical anthropology]. Buda: Magyar Királyi Egyetem, 1839.

La Langue, János. A'Magyar Országi Orvos Vizekröl, és a’ Betegségekbenn azokekal való élésnek szabott modjairól [On the medicinal waters of Hungary and the prescribed manners of using them in diseases]. Nagy-Károly: Klemann Iósef, 1783.

Lepenies, Wolf. Melancholie und Gesellschaft. Frankfurt am Main: Suhrkamp, 1998.

Linzbauer, Franciscus Xav. Codex Sanitario-Medicinalis Hungariae. Tomus III. Sectio I. Buda: Typis Caesareo-Regiae Scientiarum Universitatis, 1853.

Magyary-Kossa, Gyula. Magyar orvosi emlékek [Hungarian medical recollections]. Vol. 1. Budapest: Eggenberger, 1929.

Mátyus, István. Diaetetica. Vol. 2. Kolozsvár: Páldi István, 1766.

Mátyus, István. Ó és új diaetetica [Old and new dietetics]. Vol. 1. Pozsony: Mihály Landerer, 1787.

McGann, Jerome. "Rethinking Romanticism.” ELH 59, no. 3 (1992): 735-54. doi: $10.2307 / 2873450$

Melius, Peter. Herbarium Az Faknac Fvveknec nevekröl, természetekröl, és has znairol [Herbarium: The names, nature, and uses of trees and herbs]. Colosuárat: Heltai Gáspárne, 1578. 
Németh, László. Berzsenyi Dániel. Budapest: Franklin-Társulat, [1939].

Pápai Páriz, Ferenc. Pax Corporis. Edited by Ferenc Szablyár. Budapest: Magvető, 1984.

Porter, Roy. The Greatest Benefit to Mankind: A Medical History of Humanity from Antiquity to the Present. London: Fontana Press, 1999.

Puder, Sándor dr. Mit köszönhet az irodalom az orvostudománynak? Az. orvostudomány és a szépirodalom. Müvelódéstörténeti és irodalomtörténeti tanulmány [What has literature given medicine? Medicine and fiction. A study in the history of culture and literature]. Az Orvosi Hetilap Tudományos Közleményei. Különlenyomat. Budapest: Centrum Kiadóvállalat R.-T., 1933.

Rácz, Sámuel. Orvosi oktatás, mellyben a’ leg Gyakrabb és leg közönségesebb nyavalyáknak jelei és orvosságai röviden le-iratnak. [Medical teaching, in which the signs and medications of the most frequent and common ailments are described briefly]. Vol. 1. Buda: Landerer Katalin, 1776.

Rey, Roseleyne. The History of Pain. Translated by Louise Elliott Wallace, J. A. Cadden, and S. W. Cadden. Cambridge-Massachusetts-London: Harvard University Press, 1998.

Richards, I. A. Practical Criticism: A Study of Literary Judgement. Second edition. London: Kegan Paul, Trench \& Co. Ltd., 1930.

Richter, Christian Friedrich. Erkenntniss des Menschen, sonderlich nach dem Leibe und natürlichen Leben, oder ein deutlicher Unterricht von der Gesundheit und deren Erhaltung [...]. Leipzig: Johann Friedrich Gleditsch, 1741.

Richter, Franz. Tanácsadó mindazokra nézve, a’ kik az aranyérben kissebb vagy nagyobb mértékeben szenvednek. [Guidance for all who suffer from hemorrhoids to a lesser or greater extent]. Translated and expanded by József Horvát. Pest: Hartleben K. Adolf, 1830.

Rónay, Mária. "A rejtélyes Berzsenyi Dániel - a pszichopatológia tükrében" [The mysterious Dániel Berzsenyi: In light of psychopathology]. Pesti Hirlap, February 2, 1936.

Schedel, Ferenc. Dietetica' elemei: Hallgatói' számára [Elements of dietetics: For students]. Buda: M. Királyi Egyetem, 1839.

Schwanitz, H. J. Die Theorie der praktischen Medizin zu Beginn des 19. Jahrbunderts. Cologne: Pahl-Rugenstein Verlag, 1979.

Störck, Anton von. Orvosi praxis [Medical practice]. Translated and expanded by Sámuel Rácz. Vol. 1. Buda: Pesti Királyi Universitas, 1801.

Szirmay-Pulszky, H. von. Genie und Irsinn im Ungarischen Geistleben. Munich: Ernst Reinhardt, 1935. 
Váli, Mihály. Ház̨i orvos szótárotska [A small dictionary of home medicine]. Győr: Streibig József, 1792.

Zacharides, Georgius. Dissertatio Inauguralis Medica de Diaeta et Regimene Hypochondriacorum. Halae Magdeburg: Joannis Christiani Hendel, 1750.

Zákonyi, Ferenc. Balatonfüred: Adalékok Balatonfüred történetéhez a kezdetketól 1945-ig [Balatonfüred: Additions to the history of Balatonfüred from the beginnings until 1945]. Veszprém, 1988.

Zay, Sámuel. Falusi orvos pap, vagy olly orvosi útmutatás, mellynél fogva leginkább a’ Falukon uralkodni szokott nyavalyák orvoslatnak [Village physician priest, or medical guidance through which diseases dominant mainly in villages are remedied]. Pozsony: Wéber Simon Péter, 1810. 